\title{
Mathematical modeling and determination of thermodynamic properties of jabuticaba peel during the drying process
}

\author{
Cristian F. Costa ${ }^{1}$, Paulo C. Corrêa ${ }^{1}$, Jaime D. B. Vanegas ${ }^{1}$, \\ Fernanda M. Baptestini ${ }^{1}$, Renata C. Campos ${ }^{1} \&$ Lara S. Fernandes $^{1}$
}

${ }^{1}$ Universidade Federal de Viçosa/Departamento de Engenharia Agrícola. Viçosa, MG. E-mail: cristianfernandescosta@gmail.com (Corresponding author); copace@ufv.br; jdbustosv@gmail.com; fbaptestini@yahoo.com.br; renata.eal@hotmail.com; lara.santanaf@gmail.com

Key words:

Myrciaria jaboticaba

enthalpy

entropy

\begin{abstract}
A B S T R A C T
Jabuticaba is a fruit native of Brazil and, besides containing many nutritional qualities, it also has a good field for use in products such as flour for cakes and biscuits, juice, liqueur, jelly and others. This study aimed to model the drying kinetics and determine the thermodynamic properties of jabuticaba peel at different drying air temperatures. Ripe fruits of jabuticaba (Myrciaria jaboticaba) were collected and pulped manually. Drying was carried out in a forced-air circulation oven with a flow of $5.6 \mathrm{~m} \mathrm{~s}^{-1}$ at temperatures of $40,50,60$ and $70{ }^{\circ} \mathrm{C}$. Six mathematical models commonly used to represent the drying process of agricultural products were fitted to the experimental data. The Arrhenius model was used to represent the drying constant as a function of temperature. The Midilli model showed the best fit to the experimental data of drying. The drying constant increased with the increment in drying temperature and promoted an activation energy of $37.29 \mathrm{~kJ} \mathrm{~mol}^{-1}$. Enthalpy and Gibbs free energy decreased with the increase in drying temperature, while entropy decreased and was negative.
\end{abstract}

\section{Palavras-chave:} Myrciaria jaboticaba entalpia entropia

\section{Modelagem matemática e propriedades termodinâmicas da casca da jabuticaba durante o processo de secagem}

\begin{abstract}
R E S U M O
A jabuticaba é um fruto nativo do Brasil e além de conter muitas qualidades nutricionais também possui bom campo para a utilização em subprodutos como farinhas para bolos e biscoitos, suco, licor, geleia e outros. Objetivou-se modelar a cinética de secagem e determinar as propriedades termodinâmicas de casca de jabuticaba em diferentes temperaturas do ar de secagem. Foram utilizadas jabuticabas maduras, colhidas e separadas da polpa manualmente, da espécie Myrciaria jaboticaba. A secagem foi realizada em estufa de circulação forçada de ar com velocidade de $5,6 \mathrm{~m} \mathrm{~s}^{-1}$ nas temperaturas de 40;50; 60 e $70{ }^{\circ} \mathrm{C}$. Seis modelos matemáticos usualmente utilizados para a representação do processo de secagem de produtos agrícolas foram ajustados aos dados experimentais. A relação do tipo Arrhenius foi utilizada para representar a constante de secagem em função da temperatura. O modelo de Midilli foi o que melhor se ajustou aos dados experimentais da secagem. A constante de secagem aumentou com o incremento da temperatura de secagem e proporcionou energia de ativação de 37,29 $\mathrm{kJ} \mathrm{mol}^{-1}$. A entalpia e a energia livre de Gibbs diminuíram com o aumento da temperatura de secagem; já a entropia diminuiu e foi negativa.
\end{abstract}




\section{INTRODUCTION}

Jabuticaba peel dehydration is a plausible and concrete alternative, because it adds value to the product and diversifies its use. With the dehydrated peel, it is possible to make flour, which can be easily included in diets through cakes, biscuits, pasta and even isotonic beverages (Ascheri et al., 2006). However, drying is a process of heat and mass transfer that must be well understood in order to achieve efficiency, from technical and economic perspectives.

Mathematical modeling allows predicting and simulating the behavior of certain parameters and processes, through empirical and phenomenological models. Although they do not usually have theoretical foundation, empirical models are generally simple and easily applied, since they are based on experimental data, dimensional and statistical analyses. Phenomenological models are based on theories and laws, are more complex and involve parameters that reflect the physical nature of the system, which can also be obtained to represent the actual system (Lisbôa et al., 2015).

The thermodynamic study in the drying processes of agricultural products is fundamental for the designing and dimensioning of devices in various processes of preservation of product quality, as well as in the comprehension and provision of information regarding the energy exchanges that occur from one equilibrium state to another (Oliveira et al., 2014). The study of thermodynamic properties of a product aims to solve problems related to stability and optimization issues of the conditions of industrial processes (Marcinkowski, 2006).

Given the above, this study aimed to model the drying kinetics and determine the thermodynamic properties of jabuticaba peel at different drying air temperatures.

\section{Material ANd Methods}

The present study was carried out at the Laboratory of Physical Properties and Evaluation of Agricultural Products' Quality, at the National Center of Training in Storage (CENTREINAR), located on the Campus of the Federal University of Viçosa, in Viçosa-MG, Brazil.

Ripe fruits of jabuticaba (Myrciaria jaboticaba), from Viçosa-MG, were collected and the pulp was separated from the peel. After separation, the moisture content was determined through gravimetry method in an oven at $105 \pm 3{ }^{\circ} \mathrm{C}$ for $24 \mathrm{~h}$ (Brasil, 1992), in three replicates, and it was equal to $4.53 \mathrm{~kg}_{\mathrm{w}}$ $\mathrm{kg}_{\mathrm{dm}}{ }^{-1}$ (kg of water per kg of dry matter).

Drying was performed in a forced-air oven with flow of $5.6 \mathrm{~m} \mathrm{~s}^{-1}$ at the temperatures of $40,50,60$ and $70^{\circ} \mathrm{C}$. The oven (400/3ND, Nova) had dimensions of $825 \times 650 \times 680 \mathrm{~mm}$ and $1500 \mathrm{~W}$. Three removable trays with screened bottom to allow the passage of air through the sample were placed inside the device, each one containing approximately $150 \mathrm{~g}$ of product in a thin layer.

During the drying process, the trays containing the product were removed every $15 \mathrm{~min}$ from the chamber and weighed; hygroscopic equilibrium was achieved when the variation in the mass of the containers remained approximately constant during three consecutive weighings.
The moisture ratio of jabuticaba peel during the drying, under the different air conditions, was determined using the following expression:

$$
\mathrm{MR}=\frac{\mathrm{W}_{\mathrm{t}}-\mathrm{W}_{\mathrm{e}}}{\mathrm{W}_{\mathrm{i}}-\mathrm{W}_{\mathrm{e}}}
$$

where:

MR - moisture ratio, dimensionless;

$\mathrm{W}_{\mathrm{t}}$ - water content of the product at the time $\mathrm{t}$, decimal (dry basis - d.b.);

$\mathrm{W}_{\mathrm{e}}$ - equilibrium water content of the product, decimal (d.b.); and,

$\mathrm{W}_{\mathrm{i}}$ - initial water content of the product, decimal (d.b.).

Different models proposed in the literature were used to predict the drying kinetics of jabuticaba peel (Table 1):

Table 1. Mathematical models used to predict the drying phenomenon

\begin{tabular}{lll}
\hline \multicolumn{1}{c}{ Model designation } & \multicolumn{1}{c}{ Model } & Eq. \\
Approximation of diffusion & $\mathrm{MR}=\mathrm{a} \exp (-\mathrm{kt})+(1-\mathrm{a}) \exp (-\mathrm{kbt})$ & $(2)$ \\
Two-term & $\mathrm{MR}=\mathrm{a} \exp (-\mathrm{kt})+\mathrm{b} \exp (-\mathrm{ct})$ & $(3)$ \\
Verma & $\mathrm{MR}=\mathrm{a} \exp (-\mathrm{kt})+(1-\mathrm{a}) \exp (-\mathrm{bt})$ \\
Midilli & $\mathrm{MR}=\mathrm{a} \exp \left(-\mathrm{kt} \mathrm{t}^{\mathrm{c}}\right)+\mathrm{bt}$ \\
Logarithmic & $\mathrm{MR}=\mathrm{a} \exp (-\mathrm{kt})+\mathrm{b}$ \\
Page & $\mathrm{MR}=\exp \left(-\mathrm{kt} \mathrm{t}^{\mathrm{c}}\right)$ & $(6)$ \\
\hline
\end{tabular}

where:

$\mathrm{a}, \mathrm{b}$ and $\mathrm{c}$ - coefficients of the models, dimensionless;

$\mathrm{k}$ - drying constant, $\mathrm{h}^{-1}$; and,

t - time, h.

The mathematical models were fitted using non-linear regression analysis through the Gauss-Newton method in the program Statistica $8.0^{\circ}$. The best model was selected based on the statistical parameters: standard deviation of the estimate $(\mathrm{SE})$, relative mean error $(\mathrm{P})$ and coefficient of determination $\left(\mathrm{R}^{2}\right)$.

$$
\begin{aligned}
& S E=\sqrt{\frac{\sum_{i=1}^{n}(Y-\hat{Y})}{D F}} \\
& P=\frac{100}{n} \sum_{i=1}^{n} \frac{|Y-\hat{Y}|}{Y}
\end{aligned}
$$

where:

Y - observed value;

$\hat{Y} \quad$ - value estimated by the model;

DF - degrees of freedom of the model (number of experimental data minus the number of parameters of the model); and,

n - number of observed data.

The drying constant of the best fitted model was applied to the Arrhenius equation (Eq. 10). This equation shows the relationship between the activation energy and the velocity at which the reaction occurs. 


$$
\mathrm{k}=\mathrm{A}_{0} \exp \left(-\frac{\mathrm{E}_{\mathrm{a}}}{\mathrm{RT}}\right)
$$

where:

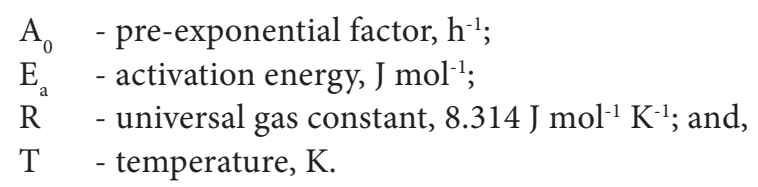

The thermodynamic properties of the drying process of jabuticaba peel were obtained through the method described by Jideani \& Mpotokwana (2009):

$$
\begin{gathered}
\Delta \mathrm{H}=\mathrm{E}_{\mathrm{a}}-\mathrm{RT} \\
\Delta \mathrm{S}=\mathrm{R}\left(\ln \mathrm{A}_{0}-\ln \frac{\mathrm{k}_{\mathrm{B}}}{\mathrm{h}_{\mathrm{p}}}-\ln \mathrm{T}\right) \\
\Delta \mathrm{G}=\Delta \mathrm{H}-\mathrm{T} \Delta \mathrm{S}
\end{gathered}
$$

where:

$$
\begin{array}{ll}
\Delta \mathrm{H} & \text { - enthalpy variation, } \mathrm{J} \mathrm{mol}^{-1} ; \\
\Delta \mathrm{S} & - \text { entropy variation, } \mathrm{J} \mathrm{mol}^{-1} \mathrm{~K}^{-1} ; \\
\Delta \mathrm{G} & - \text { Gibbs free energy variation, } \mathrm{J} \mathrm{mol}^{-1} \text {; } \\
\mathrm{k}_{\mathrm{B}} & - \text { Boltzmann constant, } 1.38 \times 10^{-23} \mathrm{~J} \mathrm{~K}^{-1} \text {; and, } \\
\mathrm{h}_{\mathrm{p}} & - \text { Planck constant, } 6.626 \times 10^{-34} \mathrm{~J} \mathrm{~s}^{-1} \text {. }
\end{array}
$$

\section{Results AND Discussion}

The values of $\mathrm{P}, \mathrm{SE}$ and $\mathrm{R}^{2}$ for each model considered in the present study, under the evaluated drying conditions, are shown in Table 2.

According to Corrêa et al. (2010), the coefficient of determi-

\begin{tabular}{|c|c|c|c|c|c|c|}
\hline Models & $\mathbf{R}^{2}$ & $P(\%)$ & SE & $\mathbf{R}^{2}$ & $P(\%)$ & SE \\
\hline & \multicolumn{3}{|c|}{ Temperature $40^{\circ} \mathrm{C}$} & \multicolumn{3}{|c|}{ Temperature $50^{\circ} \mathrm{C}$} \\
\hline $\begin{array}{l}\text { Approximation } \\
\text { of diffusion }\end{array}$ & 0.9991 & 3.267 & 0.012 & 0.9989 & 6.433 & 0.013 \\
\hline Two-term & 0.9991 & 3.267 & 0.012 & 0.9993 & 4.376 & 0.011 \\
\hline Logarithmic & 0.9991 & 3.771 & 0.012 & 0.9994 & 6.033 & 0.010 \\
\hline Midilli & 0.9999 & 1.512 & 0.004 & 0.9998 & 1.804 & 0.005 \\
\hline Page & 0.9994 & 4.569 & 0.009 & 0.9997 & 5.602 & 0.007 \\
\hline \multirow[t]{2}{*}{ Verma et al. } & 0.9991 & 3.267 & 0.012 & 0.9993 & 4.376 & 0.011 \\
\hline & \multicolumn{3}{|c|}{ Temperature $60^{\circ} \mathrm{C}$} & \multicolumn{3}{|c|}{ Temperature $70^{\circ} \mathrm{C}$} \\
\hline $\begin{array}{l}\text { Approximation } \\
\text { of diffusion }\end{array}$ & 0.9970 & 19.912 & 0.023 & 0.9970 & 20.290 & 0.023 \\
\hline Two-term & 0.9980 & 11.823 & 0.018 & 0.9980 & 13.412 & 0.019 \\
\hline Logarithmic & 0.9983 & 22.951 & 0.017 & 0.9984 & 20.675 & 0.017 \\
\hline Midilli & 0.9999 & 7.548 & 0.004 & 0.9999 & 2.861 & 0.002 \\
\hline Page & 0.9998 & 16.977 & 0.006 & 0.9998 & 13.032 & 0.005 \\
\hline Verma et al. & 0.9980 & 11.825 & 0.018 & 0.9980 & 13.411 & 0.019 \\
\hline
\end{tabular}
nation for non-linear models is a good tool for decision-taking, and it is necessary a joint analysis of the three statistical parameters. However, $\mathrm{R}^{2}$ showed high values and was above $99 \%$ for all treatments.

Table 2. Mean values of relative mean error $(\mathrm{P} \%)$, standard deviation of the estimate (SE) and coefficient of determination $\left(\mathrm{R}^{2}\right)$ for the mathematical models of drying of peel of jabuticaba (Myrciaria jaboticaba)
Among the evaluated models, Midilli showed the best fit to the observed data of moisture ratio. While the other analyzed models showed SE between 0.004 and 0.023 , Midilli SE from 0.002 to 0.005 under the different experimental conditions.

It is desirable a value of $\mathrm{P}<10 \%$ (Mohapatra \& Rao, 2005; Costa et al., 2015). At all temperatures, the values obtained with the Midilli equation remained below this limit.

In the context of thin-layer drying models, Doymaz et al. (2006) evaluated the drying of dill (Anethum graveolens L.) and parsley (Petroselinum crispum L.) leaves and found that the Midilli model was the most adequate to describe the drying curves at temperatures from 40 to $70^{\circ} \mathrm{C}$. Martinazzo et al. (2007), in the drying of leaves of lemon grass (Cymbopogon citratus (D.C.)), observed that Midilli was the best model to describe the drying curves at temperatures from 30 to $60^{\circ} \mathrm{C}$. In addition, Reis et al. (2011), evaluating the drying of Cumari do Pará pepper (Capsicum chinense Jacqui) at temperatures of 45,55 and $65^{\circ} \mathrm{C}$, found that the Midilli model was the most adequate, corroborating with the present study.

For better analysis of the model fitted to the experimental data, Figure 1 shows the comparison of observed and estimated values of moisture ratio with the Midilli model during the drying of the product at the temperatures of 40, 50, 60 and $70{ }^{\circ} \mathrm{C}$. The data are close to the line that passes through the origin and, theoretically, they represent the equality between experimental and estimated values.

Figure 2 shows the behavior of moisture ratio as a function of the drying time of jabuticaba peel under the four different

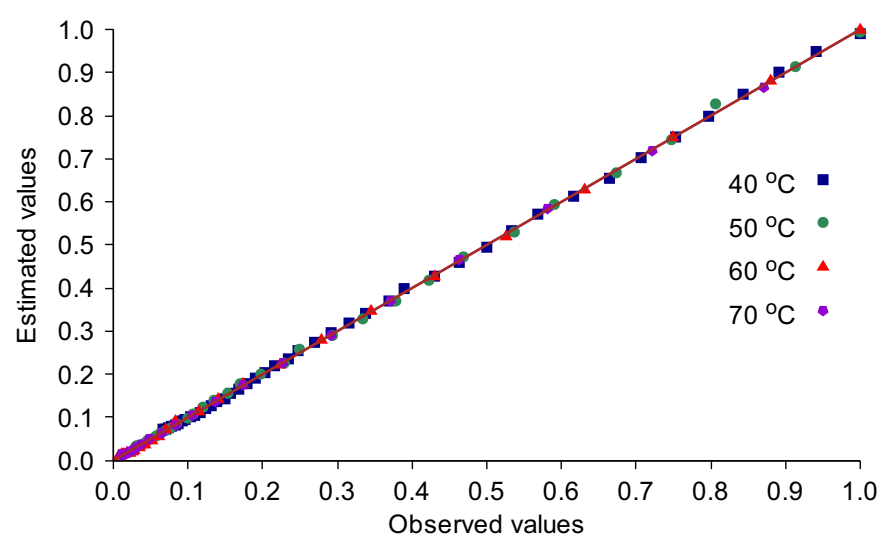

Figure 1. Observed and estimated values of moisture ratio with the Midilli model for the drying of jabuticaba (Myrciaria jaboticaba) peel

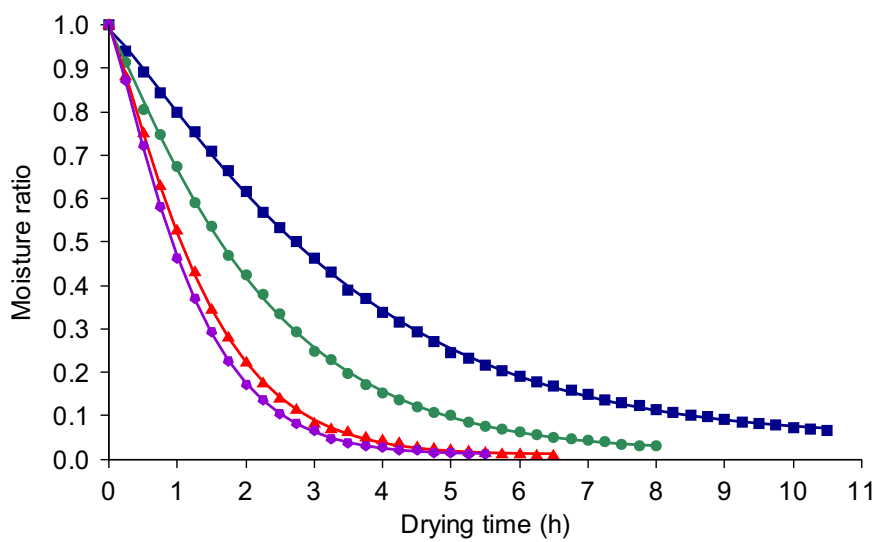

Figure 2. Drying curves of jabuticaba (Myrciaria jaboticaba) peel estimated by the Midilli model for the different drying temperatures 
conditions evaluated, as well as the values estimated for the drying process by the Midilli model.

The higher the drying temperature, the shorter is the time for jabuticaba peel to reach the equilibrium moisture (Figure 2). Such difference directly interferes with the " $k$ " value, the drying constant. The drying times corresponding to the temperatures of $40,50,60$ and $70{ }^{\circ} \mathrm{C}$ were, respectively, 10.50 , $8.00,6.50$ and $5.50 \mathrm{~h}$.

In addition, at the beginning of the drying (Figure 2), the moisture ratio has a sharper decrease because the biological material shows high water content, around $4.53 \mathrm{~kg}_{\mathrm{w}} \mathrm{kg}_{\mathrm{dm}}{ }^{-1}$, which accelerates the water loss. This occurs because, when the moisture content of the biological product is above this range, the internal resistance to water transport is lower than the external resistance to the removal of moisture from the surface, which characterizes the period of constant drying rate. Based on that, there is an internal resistance to water transport and the mechanism is controlled by diffusion. According to Oliveira et al. (2006), in this drying period, the decreasing rate corresponds to the internal water migration that constitutes the drying kinetics.

The fitted equations of the Midilli model for the studied temperatures are shown in Table 3. The drying constant increases in absolute values with the increase in drying temperature.

Figure 3 shows " $k$ " values in the form of "ln $k$ " described as a function of the inverse absolute temperature $(1 / \mathrm{T})$. The obtained line indicates the uniformity of variation of the drying constant with temperature.

The drying constant " $k$ " increased in absolute value with the increment in drying temperature, since there is larger amount of heat transferred from the air to the material and, consequently, there is an increase in the velocity of migration of the water present inside the product to the surface. The variations in the parameters (a), (n) and (b) are more related to

Table 3. Midilli model fitted to the experimental data of drying of jabuticaba (Myrciaria jaboticaba) peel

\begin{tabular}{ccc}
\hline $\begin{array}{c}\text { Temperatur e } \\
\left({ }^{\circ} \mathbf{C}\right)\end{array}$ & Midilli & $\mathbf{R}^{2}$ \\
40 & $\mathrm{MR}=0.9899 \exp \left(-0.2194 \mathrm{t}^{1.1654}\right)+0.0036 \mathrm{t}$ & 0.9998 \\
50 & $\mathrm{MR}=0.9937 \exp \left(-0.4021 \mathrm{t}^{1.1183}\right)+0.0018 \mathrm{t}$ & 0.9998 \\
60 & $\mathrm{MR}=0.9986 \exp \left(-0.6548 \mathrm{t}^{1.2034}\right)+0.0016 \mathrm{t}$ & 0.9999 \\
70 & $\mathrm{MR}=1.0024 \exp \left(-0.7673^{1.1994}\right)+0.0019 \mathrm{t}$ & 0.9999 \\
\hline
\end{tabular}

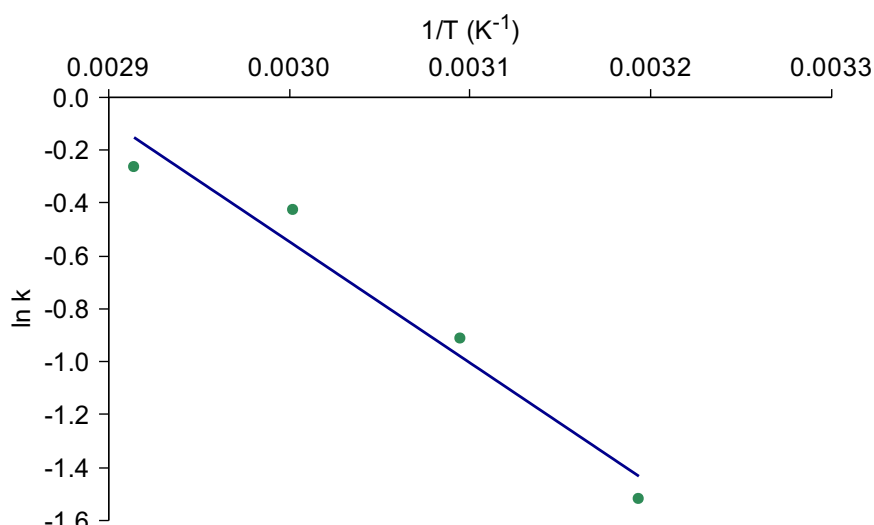

Figure 3. Arrhenius equation graph for the relationship between the drying rate and the absolute temperature in the drying of peel of jabuticaba (Myrciaria jaboticaba) mathematical fits than to a drying phenomenon, since Midilli is a semi-empirical model (Midilli et al., 2002).

The slope of the line provides the $\mathrm{E}_{\mathrm{a}} / \mathrm{R}$ relationship, while its intersection with the $\mathrm{Y}$-axis indicates the $\mathrm{A}_{0}$ value. Hence, the Arrhenius relationship can be written as:

$$
\mathrm{k}=546888.37 \exp \left(\frac{37289.95}{\mathrm{RT}}\right)
$$

The activation energy calculated from the line obtained in Figure 3 was $37.29 \mathrm{~kJ} \mathrm{~mol}^{-1}$. According to Corrêa et al. (2010), in the drying processes, the lower the activation energy, the higher will be the water diffusivity in the product, i.e., the lower will be the energy necessary for the physical transformation to occur, which refers to the transformation of liquid free water to vapor (drying).

Thermodynamically, activation energy is defined as the ease with which water molecules surpass the energy barrier during the migration inside the product (Resende et al., 2010).

The thermodynamic properties of the drying of jabuticaba peel are shown in Table 4.

Enthalpy decreased with the increase in drying temperature, which indicates that a lower amount of energy is required for the drying to occur at higher temperatures. In addition, positive values indicate the occurrence of endothermic reactions, i.e., it was necessary to provide energy in the form of heat for the physical-chemical transformations to occur.

Entropy decreased with the increment in drying temperature, indicating an increase in the order of the system, which is entropically unfavorable. According to Dannenberg \& Kessler (1988), a substance, in this case water, can have only negative entropy if the degrees of freedom of the movement of translation or rotation are lost.

Gibbs free energy is an amount that can be considered as a measurement of work performed by the system in the process of adsorption or desorption (Kaleemullah \& Kailappan, 2007). This energy provides a better view on which thermodynamic driving forces influence the reactions. In the drying of jabuticaba peel, the influence of enthalpy was clearly observed, which decreased with the increase in drying temperatures, and its positive values point to endergonic reactions, which require the supply of energy from the environment in which the product is found for the reactions to occur.

Table 4. Thermodynamic properties of drying of jabuticaba (Myrciaria jaboticaba) peel

\begin{tabular}{cccc}
\hline $\begin{array}{c}\text { Temperature } \\
\left({ }^{\circ} \mathbf{C}\right)\end{array}$ & $\begin{array}{c}\Delta \mathbf{H} \\
\left(\mathbf{J} \mathbf{~ m o l}^{-1}\right)\end{array}$ & $\begin{array}{c}\Delta \mathbf{S} \\
\left(\mathbf{J ~ m o l}^{-1} \mathbf{K}^{-1}\right)\end{array}$ & $\begin{array}{c}\Delta \mathbf{G} \\
\left(\mathrm{J} \mathrm{mol}^{-1}\right)\end{array}$ \\
40 & 34743.60 & -65.91 & 34809.51 \\
50 & 34662.29 & -66.16 & 34728.45 \\
60 & 34580.97 & -66.41 & 34647.39 \\
70 & 34499.66 & -66.65 & 34566.31 \\
\hline
\end{tabular}

\section{Conchusions}

1. The Midilli model showed the best fit to the experimental data of drying of jabuticaba (Myrciaria jaboticaba) peel.

2. The drying constant increased with the increment in drying temperature and promoted an activation energy of $37.29 \mathrm{~kJ} \mathrm{~mol}^{-1}$. 
3. In the drying of jabuticaba peel, enthalpy and Gibbs free energy decreased with the increment in drying temperature, while entropy decreased and was negative.

\section{Literature Cited}

Ascheri, D. P. R.; Ascheri, J. L. R.; Carvalho, C. W. P. Caracterização da farinha de bagaço de jabuticaba e propriedades funcionais dos extrusados. Ciência e Tecnologia de Alimentos, v.26, p.897-905, 2006. http://dx.doi.org/10.1590/S0101-20612006000400029

Brasil. Ministério da Agricultura e Reforma Agrária. Regras para análise de sementes. Brasília: SNDA/DNDV/CLAV. 365p. 1992.

Corrêa, G. C.; Oliveira, G. H. H.; Botelho, F. M.; Goneli, A. L. D.; Carvalho, F. M. Modelagem matemática e determinação das propriedades termodinâmicas do café (Coffea arabica L.) durante o processo de secagem. Revista Ceres, v.57, p.595-601, 2010. http:// dx.doi.org/10.1590/S0034-737X2010000500005

Costa, L. M.; Resende, O.; Gonçalves, D. N.; Oliveira, D. E. C. de. Modelagem matemática da secagem de frutos de crambe em camada delgada. Bioscience Journal, v.31, p.392-403, 2015. http:// dx.doi.org/10.14393/BJ-v31n2a2015-22340

Dannenberg, F.; Kessler, H. Reaction kinetics of the denaturation of whey proteins in milk. Journal of Food Science, v.53, p.258-263, 1988. http://dx.doi.org/10.1111/j.1365-2621.1988.tb10223.x

Doymaz, I.; Tugrul, N.; Pala, M. Drying characteristics of dill and parsley leaves. Journal of Food Engineering, v.77, p.559-565, 2006. http://dx.doi.org/10.1016/j.jfoodeng.2005.06.070

Jideani, V. A.; Mpotokwana, S. M. Modeling of water absorption of botswana bambara varieties using Peleg's equation. Journal of Food Engineering, v.92, p.182-188, 2009. http://dx.doi. org/10.1016/j.jfoodeng.2008.10.040

Kaleemullah, S.; Kailappan, R. Monolayer moisture, free energy change and fractionation of bound water of red chillies. Journal of Stored Products Research, v.43, p.104-110, 2007. http://dx.doi. org/10.1016/j.jspr.2005.12.001
Lisbôa, J. F.; Silva, J. N.; Cavalcanti, M. T.; Silva, E. M. C. A.; Gonçalves, M. C. Análise da hidratação de grãos de alpiste. Revista Brasileira de Engenharia Agrícola e Ambiental, v.19, p.218-223, 2015. http:// dx.doi.org/10.1590/1807-1929/agriambi.v19n3p218-223

Marcinkowski, E. A. Estudo da cinética de secagem, curva de sorção e predição e propriedades termodinâmicas da proteína texturizada de soja. Porto Alegre: UFRGS, 2006. 127p. Masters' Dissertation

Martinazzo, A. P.; Corrêa, P. C.; Resende, O.; Melo, E. de C. Análise e descrição matemática da cinética de secagem de folhas de capim-limão. Revista Brasileira de Engenharia Agrícola e Ambiental, v.11, p.301-306, 2007. http://dx.doi.org/10.1590/ S1415-43662007000300009

Midilli, A.; Kucuk, H.; Yapar, Z. A. New model for single-layer drying. Drying Technology, v.20, p.1503-1513, 2002. http://dx.doi. org/10.1081/DRT-120005864

Mohapatra, D.; Rao, P. S. A thin layer drying model of parboiled wheat. Journal of Food Engineering, v.66, p.513-18, 2005. http:// dx.doi.org/10.1016/j.jfoodeng.2004.04.023

Oliveira, D. E. C.; Resende, O.; Chaves, T. H.; Souza, K. A.; Smaniotto, T. A. S. Propriedades termodinâmicas das sementes de pinhãomanso. Bioscience Journal, v.30, p.147-157, 2014.

Oliveira, R. A. de; Oliveira, W. P. de; Park, K. J. Determinação da difusividade efetiva de raiz de chicória. Engenharia Agrícola, v.26, p.181-189, 2006. http://dx.doi.org/10.1590/S010069162006000100020

Reis, R. C.; Barbosa, L. S.; Lima, M. de L.; Reis, J. de S.; Devilla, I. A.; Ascheri, D. P. R. Modelagem matemática da secagem da pimenta Cumari do Pará. Revista Brasileira de Engenharia Agrícola e Ambiental, v.15, p.347-353, 2011. http://dx.doi.org/10.1590/ S1415-43662011000400003

Resende, O.; Ferreira, L. U.; Almeida, D. P. Modelagem matemática para descrição da cinética de secagem do feijão azuki (Vigna angularis). Revista Brasileira de Produtos Agroindustriais, v.12, p.171-178, 2010. http://dx.doi.org/10.15871/1517-8595/rbpa. v12n2p171-178 